\title{
Sistem Monitoring Kualitas Air pada Budidaya Perikanan Berbasis IoT dan Manajemen Data
}

\author{
Water Quality Monitoring System in Aquaculture \\ Based on IoT and Data Management \\ Yudhis Thiro Kabul Yunior*1, Kusrini ${ }^{2}$ \\ ${ }^{1,2}$ Universitas AMIKOM Yogyakarta \\ E-mail: *1 yudhis.yunior@studentsamikom.ac.id, ${ }^{2}$ kusrini@amikom.ac.id
}

\begin{abstract}
Abstrak
Salah satu permasalahan utama di sektor perikanan budidaya adalah sistem kontrol kualitas air yang buruk sehingga menyebabkan hama dan penyakit pada air kolam budidaya dan berdampak pada ikan yang stress dan mati. Tujuan dari pengecekan kualitas air adalah untuk mengkontrol penyakit dan bakteri pada air kolam budidaya sehingga dapat dilakukan tindakan dengan segera jika kualitas air dalam keadaan buruk. Berdasarkan permasalahan tersebut diperlukan terobosan teknologi untuk mempermudah petani ikan dalam mengkontrol kualitas air kolam budidaya. Sistem monitoring kualitas air berbasis Internet of Things (IoT) dan manajemen data sistem merupakan solusi yang tepat untuk permasalahan kontrol kalitas air pada kolam budidaya. Prinsip kerja sistem tersebut adalah dengan cara mentransfer data dari beberapa sensor kualitas air (Ph, Disolve Oxygen, Suhu, Turbidity) melalui embedded sistem pada sistem cloud computing yang kemudian data tersebut di transfer ke web server dan smartphone android sehingga petani ikan dapat memonitoring kualitas air kolam menggunakan smartphone secara realtime dan terintegrasi dengan sistem notifikasi. Jika salah satu parameter air dalam keadaaan buruk dapat dilakukan treatment air secara cepat. Dampak dari terkontrolnya kualitas air tersebut adalah meningkatkan Survival rate (SR) ikan hingga 30\% sehingga dapat meningkatkan sosial ekonomi petani ikan.
\end{abstract}

Kata Kunci-Internet of Things, Embeded sistem, Kualitas air

\begin{abstract}
One of the main problems in the aquaculture sector is a poor water quality control system that causes pests and diseases in aquaculture pond water and impacts on stressed and dead fish. The purpose of checking water quality is to control disease and bacteria in aquaculture pond water so action can be taken immediately if the water quality is in a bad state. Based on these problems a technological breakthrough is needed to facilitate fish farmers in controlling the quality of aquaculture pond water. Internet quality monitoring system based on Internet of Things (IoT) and system data management is the right solution for the problem of water quality control in aquaculture ponds. The working principle of the system is by transferring data from several water quality sensors (Ph, Dissolve Oxygen, Temperature, Turbidity) through an embedded system on a cloud computing system which is then transferred to the web server and an android smartphone so that fish farmers can monitor water quality the pool uses a smartphone in realtime and is integrated with the notification system when one of the water parameters is in a bad state so that water treatment can be done. The impact of controlled water quality is that it can increase fish survival rate (SR) by up to $30 \%$ so that it improves the socioeconomic of fish farmers.
\end{abstract}

Keywords - Internet of Things, Embeded System, Water Quality 


\section{PENDAHULUAN}

Dilihat dari kancah nasional Negara indonesia Menurut Data Badan Pusat Statistik (BPS) Tahun 2003 - 2015 setiap tahunnya budidaya ikan mengalami peningkatan dan pada tahun 2015 mencapai angka sekitar 1,5 juta orang melakukan budidaya ikan [1]. Meningkatnya sektor perikanan di Indonesia ternyata belum diimbangi oleh perkembangan ilmu pengetahuan dan teknologi yang memadai. Hal ini telah berdampak pada tidak optimalnya sistem budidaya perikanan dan bahkan sering terjadinya gagal panen akibat ikan yang dibudidayakan stres dan mati sebelum waktu panen [2]. Permasalahan utama di sektor perikanan budidaya, yaitu sistem kontrol kualitas air sehingga menyebabkan hama dan penyakit pada air kolam budidaya.

Salah satu faktor yang sangat menentukan keberhasilan budidaya adalah control kualitas air karena berdasarkan studi menyebutkan bahwa sekitar 60\% - 70\% penyebab ikan mati pada budidaya perikanan darat dikarenakan kontrol kualitas air yang buruk sehingga masalah kualitas air dalam dunia budidaya perikanan darat merupakan masalah yang harus di beri perhatian secara khusus [3]. Ditambah lagi 80\% budidaya perikanan darat masih menggunakan cara tradisional untuk melakukan kontrol kualitas air [2]. Berdasarkan berita yang dirilis oleh Dinas Peternakan dan Perikanan Kabupaten Bogor, menginformasikan bahwa masih sering terjadinya kematian masal pada kolam pembudidaya ikan disebabkan oleh adanya penurunan kesehatan kolam yang menyebabkan ikan stres sehingga berujung pada kematian [4].

Rata-rata pembudidaya Indonesia melakukan pengecekan kualitas air setelah ikan sakit atau mati, padahal apabila mereka disiplin melakukan pengecekan kualitas air, maka 95\% akan mampu mengurangi ikan stres, karena saat pembudidaya mengetahui jika kesehatan kolam menurun mereka mampu mengambil kebijakan dan tindakan agar air kolam budidaya sehat dan stabil kembali [2]. Dapat ditarik kesimpulan bahwa pembudidaya Indonesia rata-rata masih malas dan meremehkan kontrol kualitas air. Padahal dengan dilakukannya kontrol dan pengecekan kualitas air maka pembudidaya bisa mengetahui kesehatan kolam. Dengan mengetahui kesehatan kolam mereka akan mampu menganalisis penyakit dan kesehatan ikan.

Berdasarkan penelitian sebelumnya yang dilakukan oleh Rozeff Pramana "Perancangan Sistem Kontrol dan Monitoring Kualitas Air dan Suhu Air Pada Kolam Budidaya Ikan” memberi kesimpulan bahwa penggunaan teknologi dapat mempermudah petani ikan untuk melakukan control kualitas air [5].

Berdasarkan pemaparan permasalahan dan pengujian sebelumnya peneliti akan melakukan terobosan teknologi dengan memanfaatkan perkembangan teknologi dan internet yaitu sistem monitor kualitas air pada budidaya perikanan berbasis platform Internet of Things (IoT) dan management data system [6]. Sistem ini mampu memantau dan memonitoring beberapa parameter kualitas air antara lain Ph Air, Disolve Oxygen (DO), Suhu air dan Kecerahan air (Turbidity) berbasis smartphone.

Prinsip kerja sistem ini adalah mining data melalui sensor yang terpasang pada kolam melalui sistem embedded. Data yang telah tersimpan pada cloud computing sistem kemudian dikirim pada smartphone sehingga dapat dipantau melalui smartphone petani ikan. Pada sistem monitoring tersebut akan dilengkapi sistem analisa kualitas air sehingga dapat digunakan sebagai referensi pada management kualitas air pada budidaya berikutnya. Sistem ini juga dilengkapi sistem alarm otomatis sehingga akan mengirimkan notifikasi ke smartphone ketika kondisi air buruk yang kemudian akan ditindaklanjuti treatment air agar kondisi air kembali stabil. Dampak dari sistem ini adalah meningkatnya survival rate (SR) hingga 30\% sehingga dapat meningkatkan hasil panen petani ikan. Diharapkan sistem ini mampu memberikan kontribusi maksimal pada dunia perikanan Indonesia sehingga mampu meningkatkan sosial ekonomi masyarakat perikanan di Indonesia. 
Citec Journal, Vol. 6, No. 2, Juli 2019

\section{METODE PENELITIAN}

\subsection{Kerangka Berpikir Sistem}

Penelitian ini menggunakan metodologi kualitatif dengan kerangka berpikir seperti disajikan pada Gambar 1.

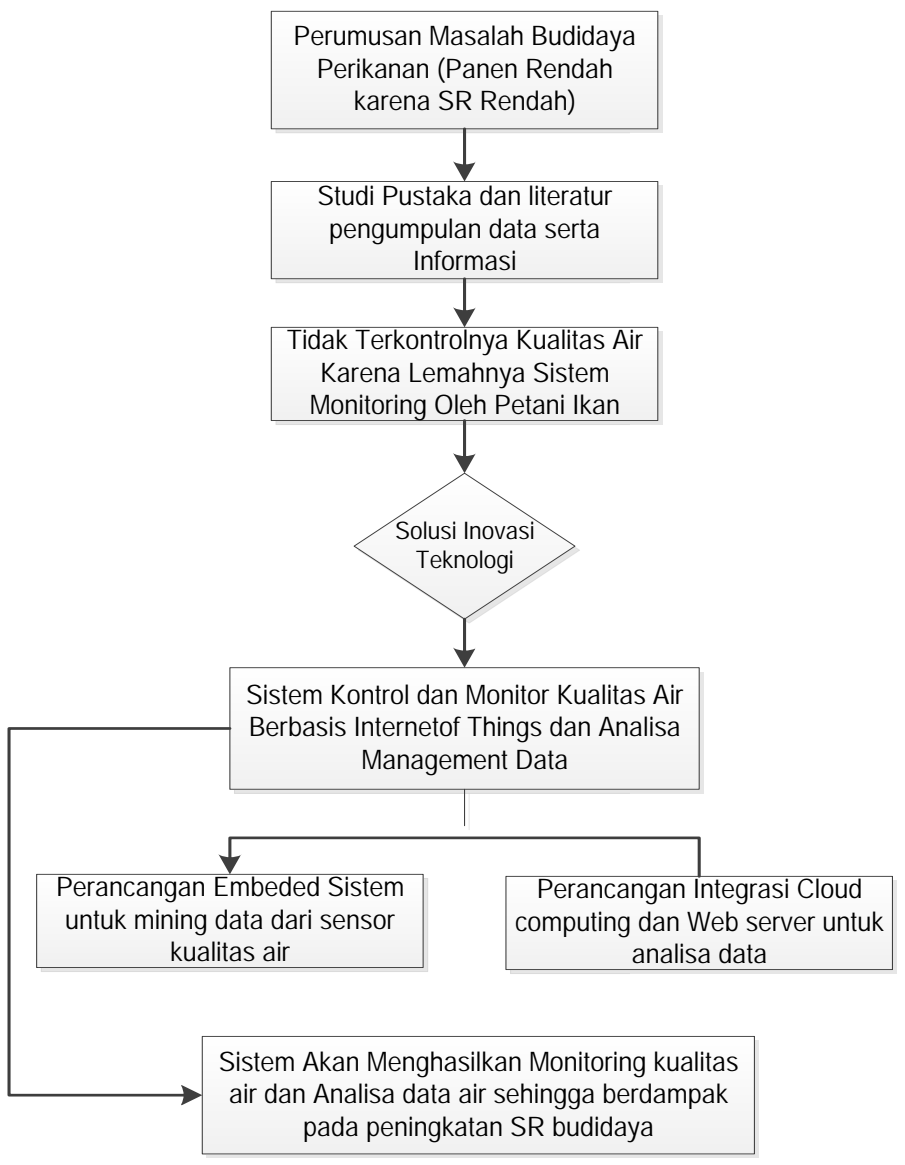

Gambar 1. Kerangka Berpikir

\subsection{Sistematika Perancangan}

Penggunaan metode kualitatif pada sistematika perancangan sistem monitoring kualitas air pada budidaya perikanan ini terdiri dari beberapa tahapan teknik atau metode penelitian yaitu teknik pengumpulan dan jenis data masalah budidaya perikanan yang dilakukan dengan melakukan studi pustaka (library research) dan penelusuran informasi digital serta berinteraksi langsung dengan para pembudidaya perikanan di beberapa daerah, kemudian berdasarkan data yang didapatkan kemudian dilakukan analisa dengan mengkaitkan informasi dari sumber bacaan dengan topik yang diangkat [7].

Metode atau teknik selanjutnya adalah teknik pengolahan data Informasi dan studi pustaka sehingga dapat dijadikan analisa data untuk menghasilkan kesimpulan yang akan digunakan untuk penerapan sistem. Metode ini dilakukan dengan menggunakan beberapa sumber yang meliputi buku pendukung, makalah online dan jurnal penelitian yang dianggap relevan dengan pembahasan pada budidaya perikanan. Jenis data yang digunakan dalam penulisan ini ialah data sekunder atau data pendukung yang merupakan data penelitian yang diperoleh peneliti secara tidak langsung, atau melalui media perantara. Teknik penulisan yang digunakan adalah deskriptif, yaitu dengan menguraikan, menjabarkan dan merangkai variabel-variabel yang diteliti menjadi sebuah pembahasannya yang runtut dan sistematis. Studi kajian deskriptif ini dilakukan 
dengan mengambil studi kasus terhadap permasalahan terhadap budidaya perikanan darat di Jawa Timur. Proses analisis dilakukan pada data-data yang terkumpul yang kemudian dipaparkan dalam pembahasan. Sintesis dilakukan dengan menggunakan studi silang (cross link) antara data yang terkumpul dengan teori dan konsep yang relevan. Kemudian dapat diambil titik utama yang kemudian diolah menjadi beberapa kesimpulan. Kesimpulan tersebut diperkuat dengan hasil uji coba perancangan sistem, saran dan rekomendasi yang terkait. Hasil kesimpulan dari analisa data tesebut merupakan penerapan teknologi dan platform Internet of Things pada sistem monitoring budidaya perikanan darat. Hasil analisa sementara menyebutkan bahwa penerapan teknologi platform Internet of Things akan dapat meningkatkan efisiensi budidaya hingga 30\% sehingga akan berdampak pada peningkatan hasil panen budidaya.

\subsection{Inovasi Teknologi Berbasis Internet of Things}

Internet of Things atau IoT, merupakan sebuah konsep yang bertujuan untuk memperluas manfaat dari konektivitas internet yang tersambung dengan sensor secara terus menerus. Konsep ini mempunyai kemampuan seperti berbagi data, remote control kepada prototipe yang telah dirancang. Komponen mikrokontroler yang telah dirancang akan bekerja dan tersambung ke jaringan internet lokal dan global. Prototipe tersebut berupa sensor, sehingga dapat memonitoring data secara real time melalui internet lokal ataupun global [8].

\subsection{Perancangan Embeded Sistem}

Embedded sistem merupakan sistem komputer yang dirancang khusus untuk tujuan tertentu demi meningkatkan fungsi suatu mesin. Embedded system ini didedikasikan untuk perintah spesifik, seperti rancangan desain untuk mengoptimasi mesin, pengurangan ukuran dan biaya produk, atau meningkatkan performa kerja. Pada Embedded system penelitian ini terdapat beberapa bagian sistem pendukung untuk mengoptimalkan sistem monitoring berbasis IoT yaitu sistem mikrokontroller menggunakan Arduino [9].

Mikrokontroler adalah perangkat yang dirancang untuk mengambil perangkat input (masukan) dari suatu alat dan mengendalikan perangkat output (keluaran) dari suatu rangkaian. Sebagian perangkat elektronik yang ada sekarang ini memiliki mikrokontroler pada bagian intinya. Mikrokontroler yang dioptimalkan untuk mengendalikan input saja atau output saja [2], sedangkan arduino adalah sebuah platform open source yang digunakan untuk membuat proyekproyek elektronika. Arduino terdiri dari dua bagian utama yaitu sebuah papan sirkuit fisik sering disebut juga dengan mikrokontroler dan sebuah perangkat lunak atau IDE (Integrated Development Environment) yang berjalan pada komputer [10].

\subsection{Pengiriman Data Pada Cloud Computing Menggunakan Modul GSM}

Pengiriman data pada perancangan sistem ini menggunakan jaringan GSM, dimana metode pengiriman adalah dengan mengintegrasikan modul GSM dengan sistem embedded sehingga dapat mengirim data dari sensor pada cloud computing yang kemudian di display pada dashboard web services [7].

\subsection{Modul GSM SIM 900 A}

SIM900A adalah modul SIM yang digunakan pada penelitian ini. Modul SIM900 GSM/GPRS adalah bagian yang berfungsi untuk komunikasi antara mikrokontroler Arduino dengan Web Service. Modul komunikasi GSM/GPRS menggunakan core IC SIM900A [8]. Modul ini mendukung komunikasi dual band pada frekuensi 900/1800 MHz (GSM900 dan GSM1800) sehingga fleksibel digunakan bersama kartu SIM dari berbagai operator telepon seluler di Indonesia. Operator GSM yang beroperasi di frekuensi dual band $900 \mathrm{MHz}$ dan 1800 MHz sekaligus adalah Telkomsel, Indosat, dan XL. Operator yang hanya beroperasi pada band $1800 \mathrm{MHz}$ adalah Axis dan Three. 
Citec Journal, Vol. 6, No. 2, Juli 2019

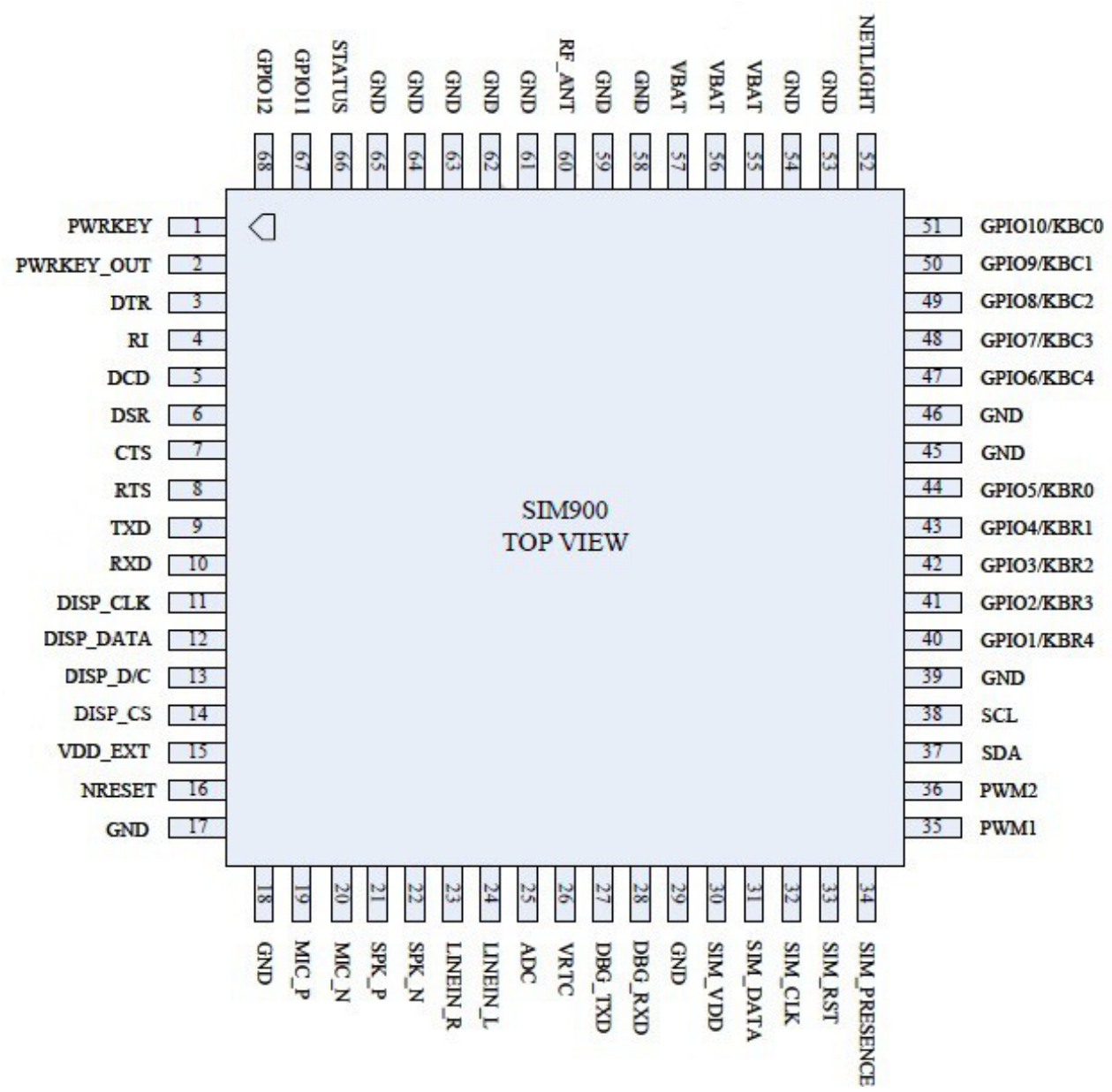

Gambar 2. Layout dan Pin-pin dari Modul SIM900

Gambar 2 merupakan tampilan dari konfigurasi pin GSM SIM900. Modul ini sudah terpasang pada breakout-board (modul inti dikemas dalam SMD/ Surface Mounted Device packaging) dengan pin header standar 0,1" (2,54 mm) sehingga memudahkan penggunaannya bahkan bagi penggemar elektronika pemula sekalipun. Modul GSM SIM900 ini juga disertakan antena GSM yang kompatibel dengan produk ini.

Spesifikasi modul GSM SIM900A adalah sebagai berikut.

1. GPRS multi-slot class 10/8, kecepatan transmisi hingga 85.6 kbps (downlink), mendukung PBCCH, PPP stack, skema penyandian CS 1,2,3,4

2. GPRS mobile station class B

3. Memenuhi standar GSM 2/2 +

4. Class4(2 W @ 900 MHz)

5. Class 1(1 W@1800MHz)

6. SMS (Short Messaging Service): point-to-point MO \& MT, SMS cell broadcast, mendukung format teks dan PDU (Protocol Data Unit)

7. Dapat digunakan untuk mengirim pesan MMS (Multimedia Messaging Service)

8. Mendukung transmisi faksimili (fax group 3 class 1 )

9. Handsfree mode dengan sirkit reduksi gema (echo suppression circuit)

10. Dimensi: 24 x 24 x 3 mm

11. Pengendalian lewat perintah AT (GSM 07.07, 07.05 \& SIMCOM Enhanced AT Command Set)

12. Rentang catu daya antara 7 Volt hingga 12 Volt DC

13. SIM Application Toolkit 
14. Hemat daya, hanya mengkonsumsi arus sebesar $1 \mathrm{~mA}$ pada moda tidur (sleep mode)

15. Rentang suhu operasional: $-40{ }^{\circ} \mathrm{C}$ hingga $+85^{\circ} \mathrm{C}$

\subsection{Quality Of Services}

Quality of Service (QoS) merupakan metode pengukuran tentang seberapa baik jaringan dan merupakan suatu usaha untuk mendefinisikan karakteristik dan sifat pada satu servis. QoS menggunakan teknik untuk mengelola throughput, delay, jitter, dan packet loss dalam jaringan. Kemampuan suatu jaringan untuk menyediakan layanan yang baik dengan menyediakan bandwith, mengatasi jitter dan delay. Parameter QoS adalah throughput, packet loss, delay, dan jitter [11]:

1. Throughput, merupakan kecepatan (rate) transfer data efektif yang diukur dalam bps. Throughput adalah jumlah total kedatangan paket yang sukses yang diamati pada destination selama interval waktu tertentu dibagi oleh durasi interval waktu tersebut.

2. Packet loss, merupakan suatu parameter yang menggambarkan suatu kondisi yang menunjukkan jumlah total paket yang hilang dapat terjadi karena collision dan congestion pada jaringan.

3. Delay latency), adalah waktu yang dibutuhkan data untuk menempuh jarak dari titik asal ke titik tujuan. Delay dapat dipengaruhi oleh jarak, media fisik, kongesti atau juga waktu proses yang lama.

4. Jitter, diakibatkan oleh variasi-variasi dalam panjang antrian, dalam waktu pengolahan data, dan juga dalam waktu penghimpunan ulang paket-paket diakhir perjalanan jitter.

\subsection{HTTP}

HTTP (Hypertext Transfer Protocol) adalah sebuah protokol untuk me-request dan meresponse sebuah data antara client seperti web browser pada user atau pada sebuah web server di suatu jaringan. Protokol ini bekerja diatas Transmission Control Protocol/Internet Protocol (TCP/IP). Client pada HTTP biasanya memulai permintaan dengan membuat hubungan TCP/IP ke port tertentu yang biasanya adalah port 80. HTTP mendefinisikan bagaimana suatu pesan dapat diformat dan dikirimkan dari client ke server atau dari server ke client. HTTP juga mengkontrol sebagai mana yang harus dilakukan oleh web server dan web browser sebagai respon dari perintah protokol HTTP tersebut [7].

\section{HASIL DAN PEMBAHASAN}

\subsection{Desain Rancang Bangun kesuluruhan Sistem}

Berdasarkan Flow sistem pada Gambar 3, pengujian akan dilakukan dengan mengambil data dari sensor parameter air (Ph, DO, Suhu, Turbidity). Data dari sensor kualitas air akan dihitung dan diolah oleh sistem mikrokontroller (Embeded Sistem) yang kemudian akan ditampilkan melalui LCD. Data dari mikrokontroller tersebut akan ditransfer menggunakan modul GSM SIM 900 ke sistem cloud untuk diolah pada web services dan kemudian dikirim ke aplikasi android smartphone. Sistem pengolahan analisa data sensor pada sistem cloud menggunakan konsep QoS pada protocol http. Sistem pengujian yang dilakukan meliputi sistem pengujian embedded sistem sensor kualitas air, pengujian transfer data pada web services dan android smrtphone serta Analisa pengiriman data pada protocol http. 
Citec Journal, Vol. 6, No. 2, Juli 2019

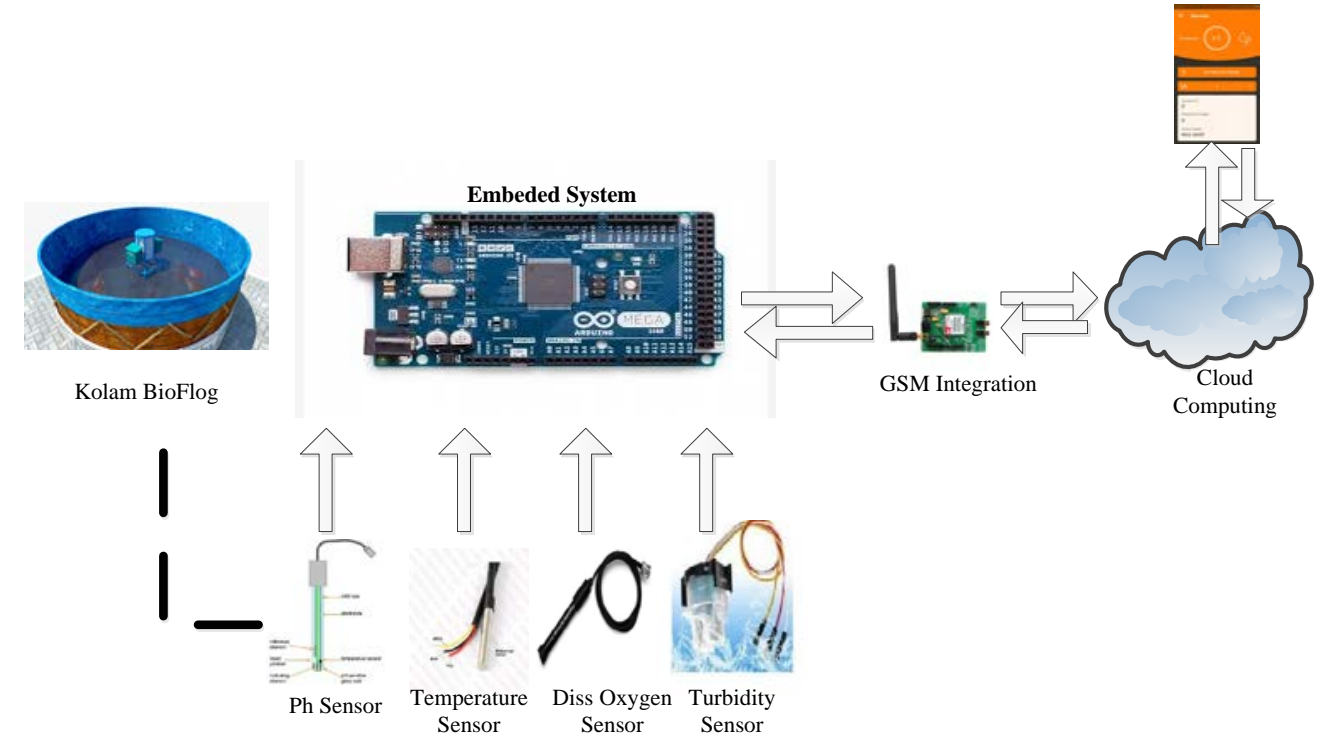

Gambar 3. Flow sistem prinsip kerja Sistem Monitoring Air Kolam berbasis IoT

\subsection{Hasil Pengujian Embeded Sistem}

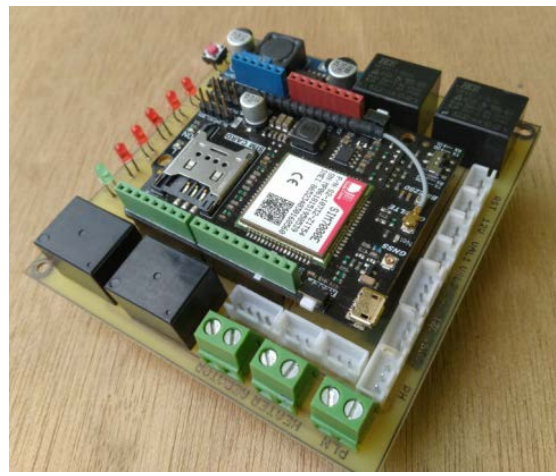

Gambar 4. Desain Hardware

Gambar 4 merupakan hardware dari sistem embedded monitoring kualitas air berbasis Internet of Things (IoT). Sistem embedded tersebut merupakan suatu sistem yang terdiri dari beberapa sistem yang saling terintegrasi untuk sistem mining data sensor hingga sistem pengiriman data menuju sistem komputasi awan (cloud system). Sistem embedded tersebut antara lain terdiri dari sistem mikro kontroller, sistem kontaktor (relay system), modul GSM untuk pengiriman data serta modul sensor untuk collect data sensor.

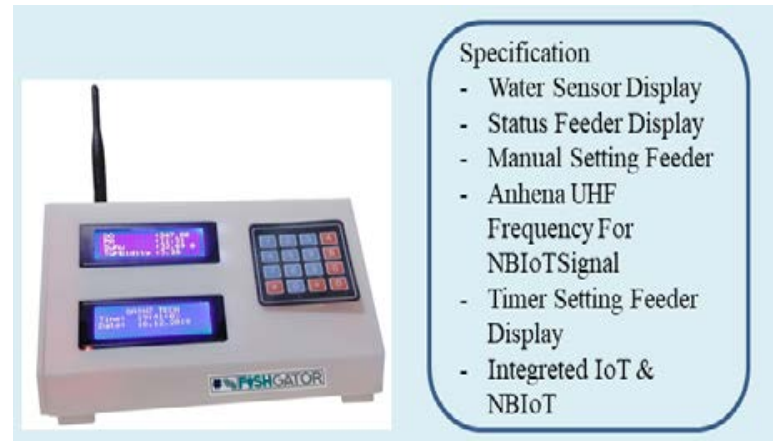

Gambar 5. Display Monitor sistem pengiriman data kualitas air kolam 
Gambar 5 merupakan display dari sistem monitoring kualitas air. Fitur dari sistem diatas antara lain display kondisi air baik secara dashboard di kolam maupun display pada android smartphone, memiliki anthena UHF dengan frekuensi sinyal NBIoT dan setting penjadwalan pemberian pakan.

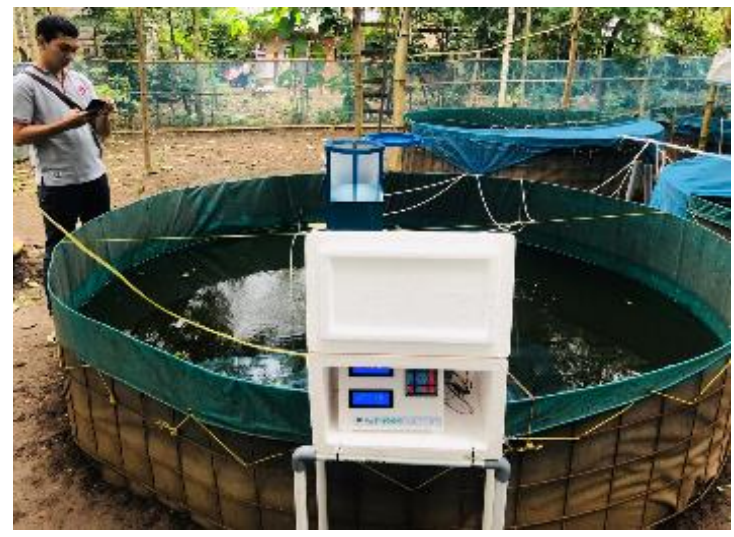

Gambar 6. Pengujian monitor kualitas air kolam pada budidaya perikanan

Sistem monitoring kualitas air berbasis platform IoT telah dilakukan pengujian secara langsung pada kolam budidaya bioflog pada beberapa pembudidaya ikan air tawar di area Jawa Timur. Hasil dari rata-rata pengujian sensor tersebut disajikan pada Tabel 1.

Tabel 1. Hasil Uji Perbandingan Pengukuran Data Sensor

\begin{tabular}{|c|l|c|c|c|}
\hline No & \multicolumn{1}{|c|}{ Jenis Sensor } & $\begin{array}{c}\text { Nilai Pengukuran } \\
\text { Menggunakan } \\
\text { Embeded Sistem }\end{array}$ & $\begin{array}{c}\text { Nilai Pengukuran } \\
\text { Menggunakan } \\
\text { Portable Sensor }\end{array}$ & $\begin{array}{c}\text { Error } \\
\text { Persen }\end{array}$ \\
\hline 1 & Sensor Ph & 7.09 & 7.12 & $0.4213 \%$ \\
\hline 2 & Sensor Disolve Oxygen (DO) & 4.45 & 4.58 & $2.8384 \%$ \\
\hline 3 & Sensor Suhu & 24.83 & 25.02 & $0.7594 \%$ \\
\hline 4 & Sensor Turbidity & 5.45 & 5.62 & $3.0249 \%$ \\
\hline
\end{tabular}

Pengujian monitoring kualitas air seperti pada Gambar 6 juga akan diintegrasikan menggunakan kosep platform Internet of Things yang terlihat pada Gambar 5, sehingga sistem monitoring akan dapat dijangkau menggunakan web services. Integrasi sensor kualitas air adalah dengan mengirim data dari sensor soil moisture melalui sistem mikrokontroller arduino dan ditampilkan pada sistem display LCD. Parameter keberhasilan pengujian adalah dengan cara membandingkan dengan sensor kualitas air portable dan menghitung error persen seperti yang terlihat pada Tabel 1. 
Citec Journal, Vol. 6, No. 2, Juli 2019

ISSN: 2354-5771

\subsection{Hasil Pengujian Web Services}

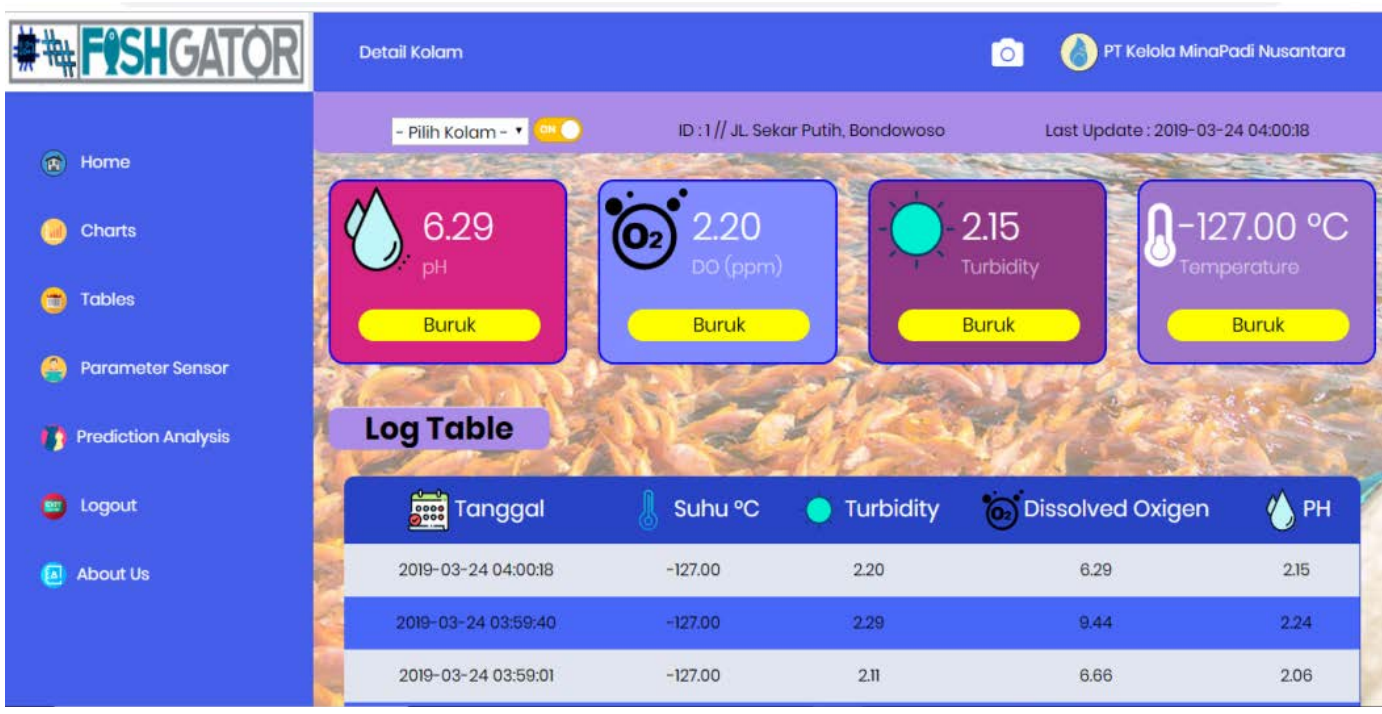

Gambar 7. Tampilan Dashboard Web Services Sistem Monitoring Kualitas Air Kolam

Gambar 7 merupakan tampilan dashboar web services pengujian sistem monitoring kualitas air berbasis platform IoT. Pada display dashoard web services tersebut terdapat tampilan nilai beberapa parameter kualitas air secara realtime dengan delay waktu pengiriman sekitar 10 menit sampai dengan 12 menit.

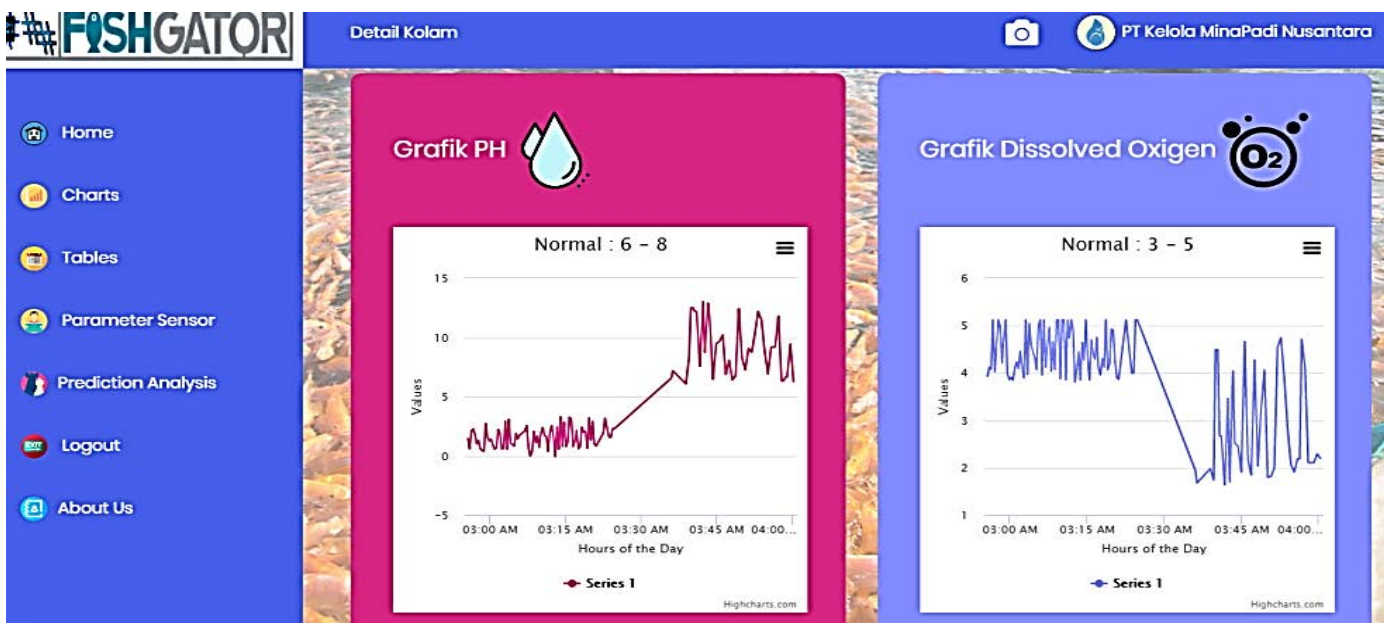

Gambar 8. Display Grafik Tracer dan Analisa Kualitas air kolam

Dari hasil pengujian pengukuran kualitas air kolam menggunakan beberapa sensor kualitas air (Ph, DO, Suhu, dan Turbidity) akan dilanjutkan pada pengiriman data pada web services menggunakan Modul GSM SIM 900 dan akan ditampilkan pada sistem dashboard web services seperti yang terlihat pada Gambar 8. Pada percobaan ini web services yang digunakan adalah Amazon Web Services. Tampilan data pada web services berupa tampilan nilai dari beberapa kualitas air, data logger dan grafik nilai sensor.

\subsection{Hasil Pengujian Pengiriman Data Menggunakan Web Services}

Untuk memastikan apakah data telah terkirim dengan benar pada sistem web services maka dilakukan sistem pengujian pengiriman data pada protocol HTTP dengan melakukan 
request dan response data sebanyak 10 kali yang menghasilkan total sebanyak 108 paket. Parameter yang digunakan untuk menghitung delay ini adalah total waktu dibagi total paket.

Tabel 2. Data pengujian pengiriman data pada web services menggunakan protocol Http

\begin{tabular}{|l|l|l|}
\hline \multicolumn{1}{|c|}{ Measurement } & Captuured & \multicolumn{1}{c|}{ Displayed } \\
\hline Packets & 108 & $108(100.0 \%)$ \\
\hline Time spam, s & 17.354 & 17.354 \\
\hline Average pps & 6.7 & 6.7 \\
\hline Average packet size, B & 118 & 118 \\
\hline Bytes & 126548 & $126548(100.0 \%)$ \\
\hline Average bytes/s & 736 & 736 \\
\hline Average bits/s & 5931 & 5931 \\
\hline
\end{tabular}

Pada Tabel 2 menunjukan nilai total waktu sebesar 17,354 sec dan total paket sebanyak 108 paket yang terdapat pada summary wireshark. Perhitungan delay dalam bentuk matematis untuk percobaan tersebut ditunjukan seperti pada persamaan 1 .

$\frac{\text { Total } \text { Waktu }}{\text { Total Paket Diterima }}=\frac{17.354}{108}=0.160685 \mathrm{sec}=160.685 \mathrm{~ms} /$ paket.

Dengan nilai delay adalah 160.685 ms/paket maka, nilai rata - rata delay tersebut masuk dalam kategori bagus dengan melihat standar indeks dari rujukan yang digunakan.

\subsection{Hasil Pengiriman Data Pada Android Smartphone}

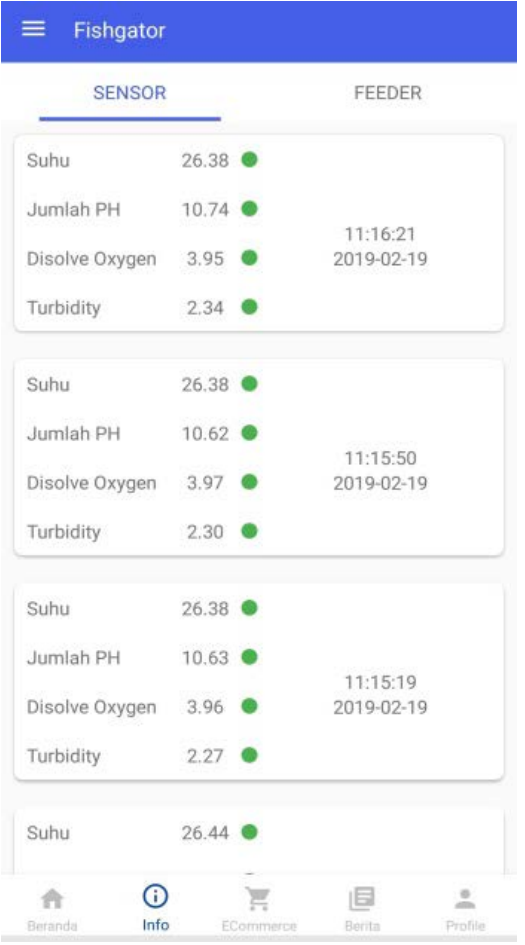

Gambar 9. Gambar uji Pengiriman Data pada android Smartphone

Pada pengujian pengiriman data melalui android Smartphone beberapa variable data yang dikirimkan antara lain data parameter kualitas air ( $\mathrm{Ph}, \mathrm{DO}$, suhu dan Turbidity) dan data gambar kondisi kolam menggunakan kamera web. Gambar 9 diatas merupakan hasil capture pada aplikasi android smartphone hasil pengiriman data sensor dan data gambar kondisi kolam. 


\section{KESIMPULAN}

Kesimpulan dari penelitian ini adalah:

1. Sistem kontrol kualitas air pada budidaya perikanan darat sangat diperlukan karena merupakan faktor penting pada keberhasilan kegiatan budidaya perikanan darat.

2. Penggunaan metode Internet of Things (IoT) merupakan dapat membantu mempermudah sistem monitoring dan kontrol kualitas air sehingga berdampak pada efisiensi sistem budidaya perikanan darat.

3. Penggunaan parameter $\mathrm{Ph}$, DO, suhu dan turbidity dilakukan sebagai identifikasi kadar kualitas air pada kolam budidaya sehingga dapat dijadikan acuan dan analisa pada pemberian rekomendasi manajemen kontrol kualitas air kolam.

4. Sistem monitoring kualitas air berbasis IoT untuk menghasilkan output identifikasi penyakit pada ikan sehingga bisa dilakukan preventif sedini mungkin.

5. Dampak dari monitoring dan kontrol kualitas air adalah menekan angka kematian ikan yang disebabkan oleh kualitas air yang buruk, sehingga dampak penggunaan sistem monitoring air kolam budidaya secara realtime tersebut berdampak pada peningkatan SR (Survical Rate) yang mampu meningkatkan kuantitas hasil panen.

\section{SARAN}

Hasil dari penelitian ini terdapat beberapa masukan dan saran antara lain:

1. Sistem ini mempunyai kelemahan pada pengaruh delay data sehingga untuk kestabilan pengiriman data diperlukan sistem jaringan yang baik.

2. Untuk kedepan diharapkan ada pengembangan agar sistem ini dilengkapi dengan sistem manajemen pakan.

3. Kualitas jaringan sangat menentukan hasil dari pengiriman data sehingga diperlukan kualitas jaringan yang baik.

\section{DAFTAR PUSTAKA}

[1] Badan Pusat Statistik, 2015, Laporan Data Perikanan, Publikasi BPS Perikanan 2014, Jakarta.

[2] Lannan, J. E., Smitherman, R. O., Tchobanoglous, G., 1983. Principles and Practices of Pond Aquaculture: A State of the Art Review, Aquanews, Oregon State University, Newport, Oregon.

[3] Boyd, C. E, 1990, Water Quality in Ponds for Aquaculture, Birmingham Publishing co. Birmingham, Alabama.

[4] Dinas Peternakan dan Perikanan Kabupaten Bogor, 2010, Buku Data Perikanan Tahun 2010, Bogor.

[5] Pramana, R., 2018, Perancangan Sistem Kontrol dan Monitoring Kualitas Air dan Suhu Air Pada Kolam Budidaya Ikan, Jurnal Sustainable, Vol. 7, No. 1, Hal. 13 - 23.

[6] Fujaya, Y., 2008, Fisiologi Ikan: Dasar Pengembangan Teknologi Perikanan, PT. Rineka Cipta, Jakarta.

[7] Al Haq, A., 2008, Perancangan Sistem Penilaian Mutu di Balai Besar Bahan dan Barang Teknik Bandung, Laporan Kerja Praktek, Fakultas Teknik Jurusan Teknik Informatika, Universitas Komputer Indonesia, Bandung.

[8] Yudhanto, Y., 2007, Apa itu IoT (Internet of things), Rumahstudio, Indonesia. 
[9] Wardoyo, S., Pramudyo. A. D., 2015, Pengantar Mikrokontroler \& Aplikasi Pada Arduin, Graha Ilmu, Yogyakarta

[10] Budiharto, W, 2014, Perancangan dan Pemrograman Hasta Karya Robot, Andi Publisher, Yogyakarta.

[11] Pratiwi, P. E., Isnawati, A. F., Hikmaturokhman, A., 2012, Analisis QoS pada Jaringan Multi Protokol Label Switching (MPLS) Studi Kasus Di Pelabuhan Indonesia III Cabang Tanjung Intan Cilacap, ResearchGate, https://www.researchgate.net/publication/306119887_ANALISIS_QoS_PADA_JARINGA N_MULTI_PROTOCOL_LABEL_SWITCHING_MPLS_STUDI_KASUS_DI_PELABU HAN_INDONESIA_III_CABANG_TANJUNG_INTAN_CILACAP, diakses pada tanggal 10 November 2019 